\title{
APPLICATION OF REMOTE SENSING BIG DATA FOR RAPID RESPOND TO LANDSLIDE LAKE DISASTER MONITOR
}

\author{
H. J. Wang ${ }^{1.2 .3}$, Y. Zhou ${ }^{1.3,}$ *, S. X. Wang ${ }^{1.3}$, F. T. Wang ${ }^{1.3, *}$, Q. Zhao ${ }^{1.3}$ \\ ${ }^{1}$ Aerospace Information Research Institute, Chinese Academy of Sciences, Beijing, China - (zhouyi, Wangsx)@radi.ac.cn \\ ${ }^{2}$ University of Chinese Academy of Sciences, Beijing, China - wanghj@radi.ac.cn \\ ${ }^{3}$ Institution of Remote Sensing and Digital Earth, Chinese Academy of Sciences, Beijing, China - (wangft, zhaoqing)@radi.ac.cn
}

Commission VI, WG VI/4

KEY WORDS: Remote Sensing Big Data, Landslide Lake, Disaster Monitor

\begin{abstract}
:
Landslide dam, a common disaster around the world, always forms landslide lake because of blocking the river. Landslide lake is always with potentially immense hazard from rapid release of a large of water masses. Nowadays, with the development of remote sense technology, remote sensing big data has been widely applied to disaster monitor, which has broad prospect in landslide lake monitor. This study provided the processing flow of remote sensing image and flow of technology system in the landslide lake monitor based on remote sensing big data, which have been successfully applied to Baige landslide lake monitor. The result shows remote sensing technology as an objective, fleet and dynamic change of landslide lake with large monitor range and meets the requirement of all-weather dynamic monitor of landslide lake, which will provide basic information of landslide lake for decisionmaking departments to make disaster prevention and reduction. Lastly, the research points out the disadvantage of landslide lake monitor based on remote sensing big data. Drone images and aerial images will be an important supplement to remote sensing big data for landslide lake monitor.
\end{abstract}

\section{INTRODUCTION}

Landslide dam was a common disaster around the world (Costa and Schuster, 1988), which always formed the landslide lake with potentially immense hazard from rapid release of a large of water masses. There were over 100,000 deaths downstream caused by the Dadu landslide dam break in Sichuan Province China in 1786 (Dai et al, 2005). The main trigger factors of landslide lake were strong earthquake and heavy rain (Wang et al, 2013), Fan (2008) counted more than 800 landslide lakes caused by the $M w 7.9$ Wenchuan earthquake in Sichuan Province, China. In terms of genesis, Schuster and Costa (1986) analysed 135 landslide lakes around the world, and the result showed that volcanic eruptions could also form landslide lakes. Yang (2008) studied the cause of typical 140 landslide lakes, landslide is the main reason of the landslide lake. In conclusion, landslide lakes formation conditions are the result of internal and external forces (Zhu, 2012; Zhao, 2015).

Lots of achievements have been obtained based on previous study. Scholars on many fields have done a lot of research on the landslide lake. Wang (2016) simulated flow process line using slope stability analysis based on circular slip mode in dam breaches in the progress of landslide dam. Meanwhile, this theory was successfully applied on the flood discharge of Tangjiashan landslide lake and Ludian landslide lake. Scholars also did lots of work on the stability of landslide dam through the analysis of the dam parameters and empirical formula (Dong et al., 2009; Xu et al., 2009). Flood evolution study of landslide dam break is another important content. Hou (2019) simulated flood discharge of Baige landslide dam based on improved two- dimensional hydrodynamic model. Landslide dam break flood accurately simulated was good for supporting disaster-relief and decision-making.

Landslide dams always occurred with bad weather and evil natural conditions. It is very difficult to promptly and quickly obtain the situation at the scene of the disaster. Especially, landslide lakes triggered by the earthquake were widely distributed and formed in large numbers (Peng et al, 2014; Fan et al, 2012; Shi et al, 2015). Hence, How to monitor the landslide lake effectively and quickly is very important. Remote sensing as a powerful and objective tool for earth observation was always applied for natural disaster monitor (Sharma et al, 2019; Kaku, 2019; Liu et al, 2019; Hoque et al, 2017; Liu et al, 2016; Westen, 2013; Zhang et al, 2012). In recent years, remote sensing technology has achieved rapid development. More than 150 satellites had been in orbit by the end of 2017 in China. The spatial and temporal resolution of satellite images were getting higher and higher. Hence, remote sensing technology had great potential in landslide lake disaster monitor.

Lots of research has been done using remote sensing technology applied on landslide lake monitor. Dong (2014) inferred landslide dam geometry using remote sensing images rapidly assessed landslide dam geometry related to dam-breach hazard critical parameters. Fan et al (2010) analysed the location, distribution characteristics and risk assessment for earthquakeinduced landslide lake using multiplatform remote sensing imagery data in Wenchuan 7.9 earthquake. Meanwhile, monitoring and assessing of landslide lakes formed after the Wenchuan earthquake was based on remote sensing image

* Corresponding author 
classification and multitemporal remote sensing data (Xu et al, 2010; Liu et al, 2009 ). This paper relied on multitemporal and multiple sensors remote sensing data for Baige landslide lake disaster monitor.

\section{STUDY AREA}

\subsection{Disaster Progress}

There were the occurrences two landslide lakes in the Jinsha River on the border of Jiangda County and Baiyu County in 2008. The first landslide lake formed at 22:06 PM on October 10,2018 , then, breach occurred on the right of the first landslide dam, Dam burst had a flow of more than $5,000 \mathrm{~m}^{3} / \mathrm{s}$. The first landslide lake disaster was eliminated until On October 16,2018 . What' more, the second landslide occurred at the site of the first landslide and formed landslide lake result from landslides blocking the Jinsha River at 17:40, on November 3, 2018. An artificial discharge tank began to discharge to eliminate the disaster at 10:50 AM, on November 12, 2018. The water level maintained stable and the disaster was obviated until 8:00 AM on November 15, 2018.

\subsection{Study Area}

Jinsha River is the upper region of the Yangtze River, which has a length of $3486 \mathrm{~km}$ and a drained area of $4.8 \times 105 \mathrm{~km}^{2}$ from Heyuan Region Qinghai Province to Yibin City Sichuan Province (Du et al., 2013). Jinsha River, located in the QinghaiTibet Plateau and North Yunnan Plateau, was also called Sheng River, Li River, Bulei River or Buliechu River in ancient times, has a total river fall of about $3300 \mathrm{~m}$ and an average slope of $0.145 \%$ (Yuan et al, 2019). The geographic location of the Jinsha River is between $90^{\circ}-105^{\circ}$ east longitude and $24^{\circ}-36^{\circ}$ northern latitude (Song et al, 2012). This area had frequent geological activities and frequent geological disasters (Zhang, 2011).

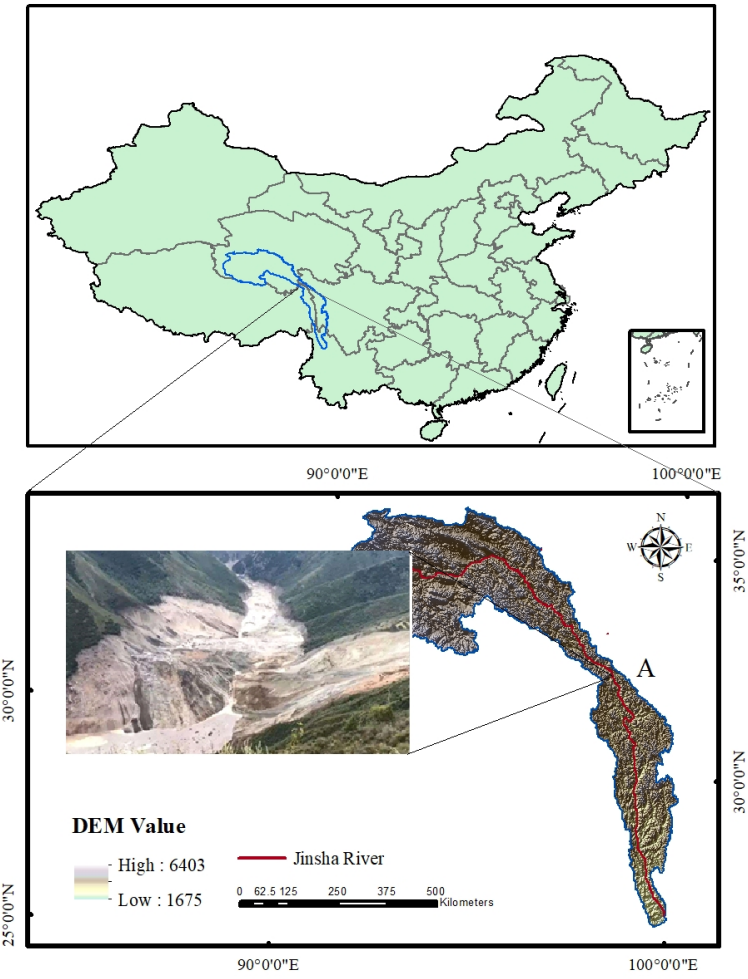

Figure 1. Location of study area

3. DATA AND METHOD

\subsection{Data}

This paper utilized multi-sensor remote sensing images for landslide lake monitor. However, weather conditions were often more complex during the occurrence of landslide lake (Xiong et al, 2012). The data used in this study as follows:

\section{Gaofen-2 image (GF-2):}

Gaofen-2 satellite was successfully launched on August 19, 2014 and the first image was obtained on August 21, 2014. Gaofen-2 satellite was independently developed by China and the first civilian optical remote sensing satellite with a spatial resolution of more than 1 meter, which carried $3.2 \mathrm{~m}$ multispectral camera and $0.8 \mathrm{~m}$ panchromatic camera. The main parameters of Gaofen-2 were showed as in Table1.

\begin{tabular}{|l|l|c|}
\hline Parameters & \multicolumn{2}{|c|}{ Camera } \\
\hline \multirow{3}{*}{ Spectral range } & panchromatic camera & $0.45-0.90 \mu \mathrm{m}$ \\
\cline { 3 - 3 } & multispectral camera & $0.45-0.52 \mu \mathrm{m}$ \\
\cline { 3 - 3 } & & $0.52-0.59 \mu \mathrm{m}$ \\
\cline { 3 - 3 } & & $0.63-0.69 \mu \mathrm{m}$ \\
\cline { 3 - 3 } & & $0.77-0.89 \mu \mathrm{m}$ \\
\hline resolution & panchromatic camera & $1.00 \mathrm{~m}$ \\
\cline { 3 - 3 } & multispectral camera & $4.00 \mathrm{~m}$ \\
\hline Image width & & $60 \mathrm{~km}$ \\
\hline Revisit cycle & & 4 days \\
\hline
\end{tabular}

Table 1. Main parameters of Gaofen-2 satellite

\section{Beijing-2 image (BJ-2):}

Beijing-2 satellite was successfully launched on 00:28 AM on July 11,2015 . With the design life of seven years, Beijing-2 
could provide remote sensing data with global coverage, high time resolution and high spatial resolution. Beijing-2 satellite also could provide spatial information support for land and resources management, agricultural resources investigation, ecological environment monitoring, urban comprehensive application and other fields. The main parameters of Beijing-2 were showed as in Table1.

\begin{tabular}{|l|c|c|}
\hline Parameters & \multicolumn{2}{|c|}{ Camera } \\
\hline Spectral range & panchromatic camera & $0.45-0.65 \mu \mathrm{m}$ \\
\cline { 3 - 3 } & multispectral camera & $0.60-0.67 \mu \mathrm{m}$ \\
\cline { 3 - 3 } & & $0.51-0.59 \mu \mathrm{m}$ \\
\cline { 3 - 3 } & & $0.44-0.51 \mu \mathrm{m}$ \\
\cline { 3 - 3 } & & $0.76-0.91 \mu \mathrm{m}$ \\
\hline resolution & panchromatic camera & $1.00 \mathrm{~m}$ \\
\cline { 3 - 3 } & multispectral camera & $4.00 \mathrm{~m}$ \\
\hline Image width & & $24 \mathrm{~km}$ \\
\hline Revisit cycle & & 2 days \\
\hline
\end{tabular}

Table 2. Main parameters of Beijing-2 satellite

\section{Sentinel-1A image:}

Sentinel-1A satellite was successfully launched on April 3, 2014. Sentinel-1A satellite carries C-band imagers at 5.405 $\mathrm{GHz}$ and offered a 12-day revisit period (Torbick et al., 2014). The main parameters of Sentinel-1A satellite are showed in Table 3. The image in this study used IW imaging mode.

\begin{tabular}{|c|c|c|c|c|}
\hline Model & SM & IW & EW & WV \\
\hline $\begin{array}{l}\text { Image } \\
\text { width }(\mathrm{km})\end{array}$ & 80 & 250 & 400 & 20 \\
\hline $\begin{array}{l}\text { incidence } \\
\text { angle }\left({ }^{\circ}\right)\end{array}$ & $\begin{array}{l}18.3- \\
46.8\end{array}$ & $\begin{array}{l}29.1- \\
46.0\end{array}$ & $\begin{array}{l}18.9- \\
47.0\end{array}$ & $\begin{array}{l}21.6-25.1 \\
34.8-38.0 \\
\end{array}$ \\
\hline $\begin{array}{l}\text { Polarization } \\
\text { mode }\end{array}$ & $\begin{array}{l}\mathrm{HH}+\mathrm{HV} \\
\mathrm{VV}+\mathrm{VH} \\
\mathrm{HH}, \mathrm{VV}\end{array}$ & $\begin{array}{l}\mathrm{HH}+\mathrm{HV} \\
\mathrm{VV}+\mathrm{VH} \\
\mathrm{HH}, \mathrm{VV}\end{array}$ & $\begin{array}{l}\mathrm{HH}+\mathrm{HV} \\
\mathrm{VV}+\mathrm{V} \\
\mathrm{H} \\
\mathrm{HH}, \mathrm{VV}\end{array}$ & $\begin{array}{l}\mathrm{HH} \\
\mathrm{VV}\end{array}$ \\
\hline $\begin{array}{l}\text { Range } \\
\text { resolution(m) }\end{array}$ & 5 & 5 & 25 & 5 \\
\hline $\begin{array}{l}\text { Azimuth } \\
\text { resolution(m) }\end{array}$ & 5 & 20 & 40 & 5 \\
\hline $\begin{array}{l}\text { Relative } \\
\text { error }\left(^{\circ}\right)\end{array}$ & 5 & 5 & 55 & 5 \\
\hline
\end{tabular}

Table 3. Main parameters of Sentinel-1A satellite

\subsection{Method}

\subsubsection{Data Progressing}

Optical Data contained multispectral image and panchromatic image, which was progressed by ENVI 5.2. The multispectral image firstly was under radiometric correction. Then, orthographical correction (RPC) was conducted for multispectral image and panchromatic image respectively. Lastly, multispectral image and panchromatic image was merged. GF-2 data processing flow chart is shown Figure 2 (Yao et al., 2019)

Radar Data was progressed by the SARscape module of ENVI 5.2. The SARscape provided graphical operation interface, and it also had an ability of processing and analysis of Radar images. This study used Sentinel-1A image. Processing steps of
Sentinel-1A image included back scattering coefficient and suppressed the speckle and geographic encoding. Radar images flow chart was showed in Figure 2 (Xiong et al., 2012).

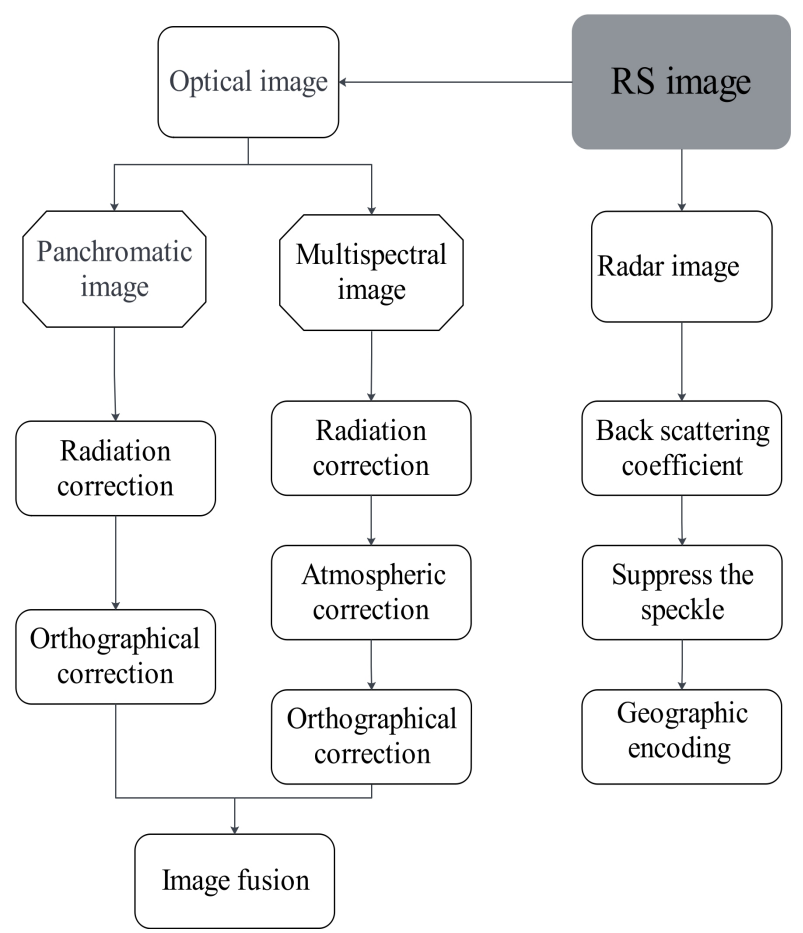

Figure 2. Processing flow chart of RS image

\subsubsection{Landslide Lake Extraction Method}

Landslide lake always formed a large lake result from blocking river by landslide and debris flow (Schuster and Costa., 1986). Therefore, extraction of landslide lake was essentially water extraction.

On optical images, the absorption of electromagnetic waves from natural water was obviously higher than most of other surface objects, so the total radiation level of water was lower than other surface objects, and remote sensing image colour presented pale. The influence of water in the near infrared and middle infrared bands was very obvious. However, the absorption energy of vegetation and soil in these two bands were small and had high reflectivity result from low reflection energy of water in these two bands. Hence, water reflectivity in the near infrared and middle infrared bands was different from vegetation and soil reflectivity. We could construct corresponding indexs for water extraction, such as NDWI et al in optical multiband image (Yi and Wang., 2007).

In the radar image, the absorption of radar wave by water is quite complete. and the boundary between land and water was black and white. We could distinguish water body from other ground objects by setting suitable threshold value based on gray level difference between water and other ground objects (Yang et al., 1998).

\subsubsection{Technology System}

The heavy rain and strong earthquake were main trigger factors for the occurrence of landslide lake. It was often rainy and 
cloudy after the landslide lake appeared. Optical remote sensing images were difficult to monitor landslide lake, because visible/near-infrared spectrum was unable to penetrate clouds. Radar images make up this flaw.

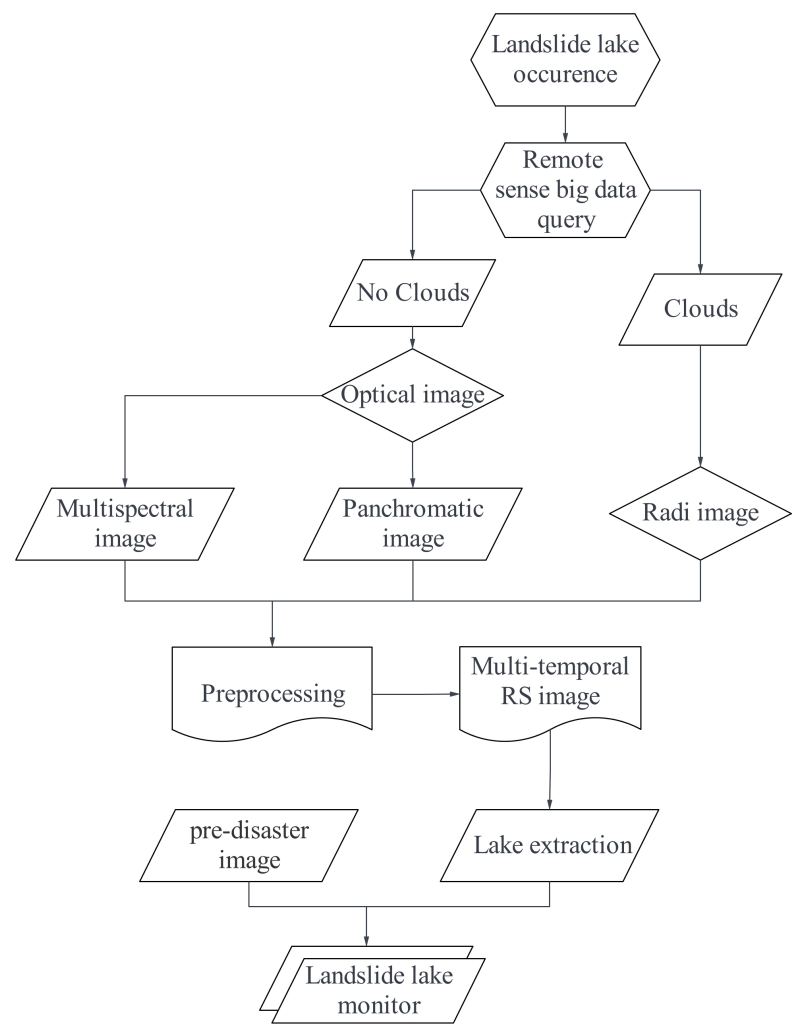

Figure 3. Flow chart of technology System

After the landslide lake formed, we should investigate and survey transit satellite and prepare to download corresponding remote sensing images in the first place. Some necessary preconditioning work should be carried out as showed in Figure 2 . Meantime, it was very important to check weather conditions. If it is not cloudy, we should select optical image to monitor the landslide lake, and we can extract water body by visual interpretation, NDWI and other classification methods in multispectral image. but, water body extraction only by visual interpretation results form only one band in panchromatic image. However, it was cloudy, it's feasible to use radar images to monitor the landslide lake and extract the water range. Based on remote sensing big data, we could monitor the landslide lake in time series from the occurrence of landslide lake to the disappearance of landslide lake. we could monitor the landslide lake in time series from the occurrence of landslide lake to the disappearance of landslide lake.

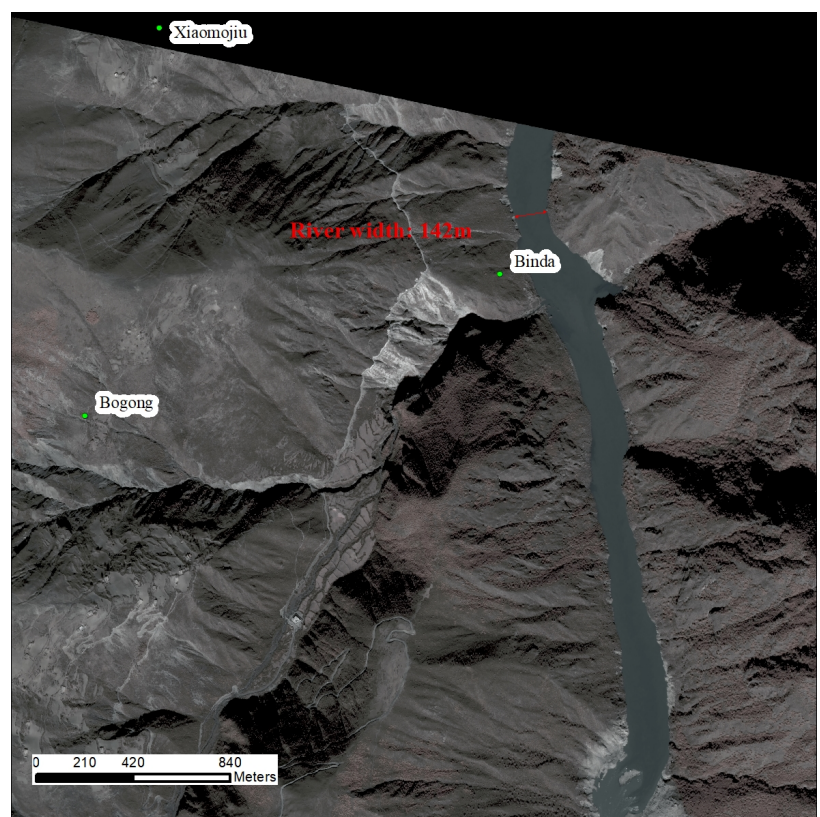

Figure 4. Landslide lake pre-disaster GF-2 image

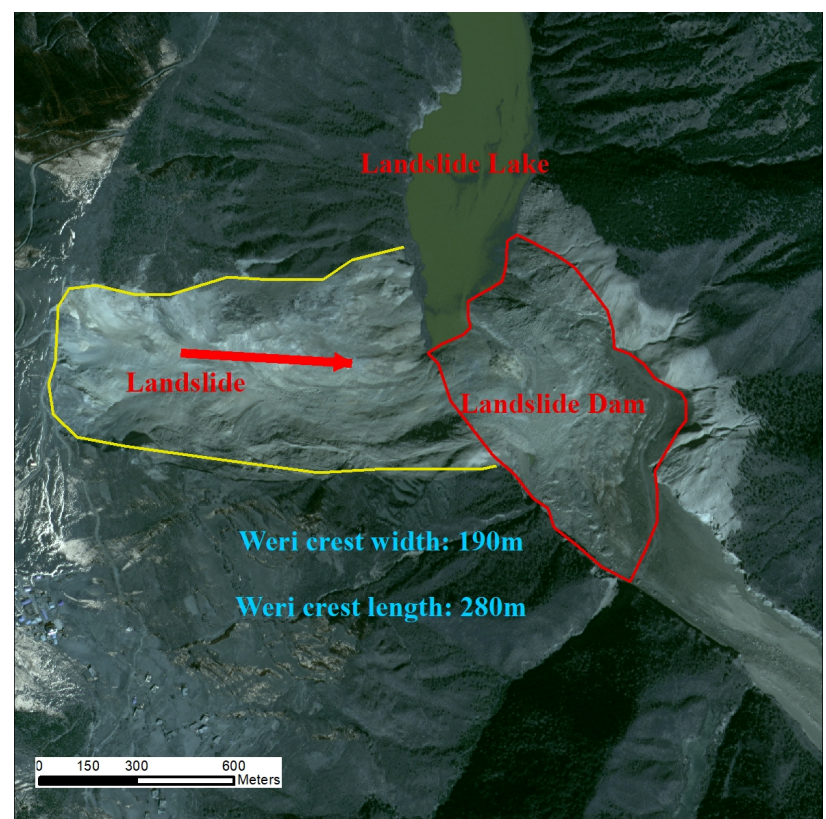

Figure 5. Landslide lake post-disaster BJ-2 image

After the pre-disaster image and post-disaster image were compared, landslide lake distribution was obtained on two phases before and after landslide lake. The areas with obvious changes in water area were probably the disaster areas. In addition, landslide lake in time series monitor was a basis for supporting landslide lake disaster-relief and decision-making, such as landslide dam parameters, lake water level and lake water area.

\section{RESULT}

From the flow chart above, remote sensing big data was applied to monitor Baige landslide lake. This study selected the 


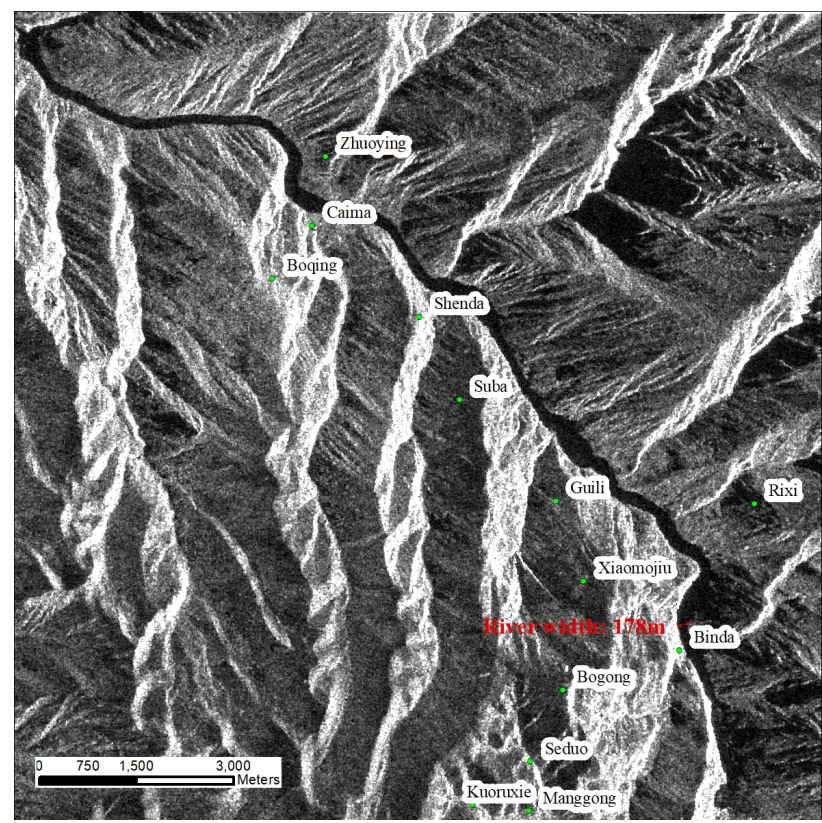

Figure 6. Sentinel-1A image on Nov 4, 2018

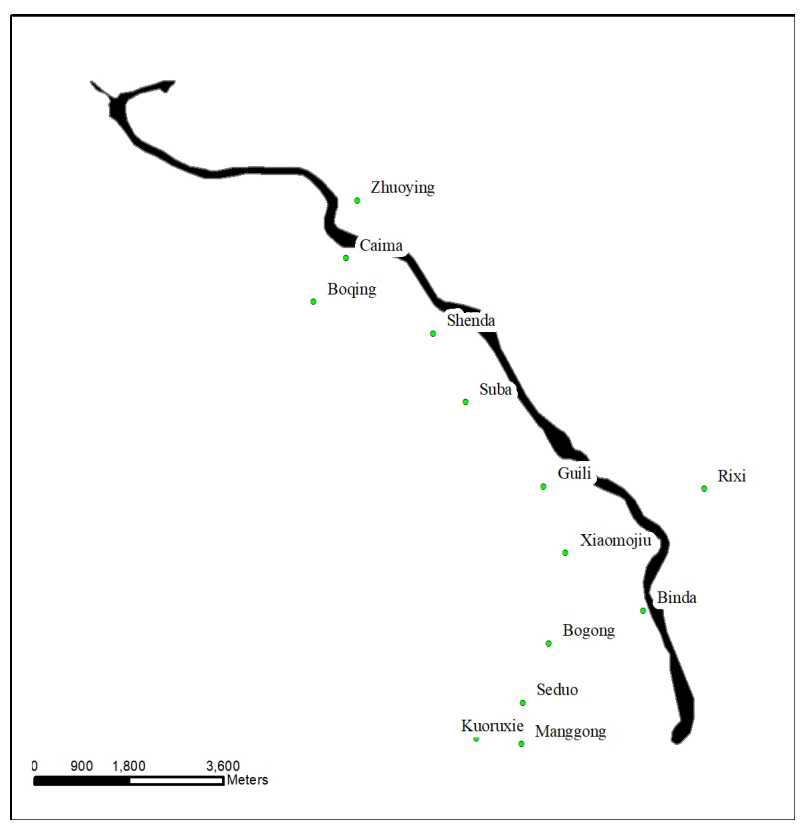

Figure 7. Water extraction result from Sentinel-1A image

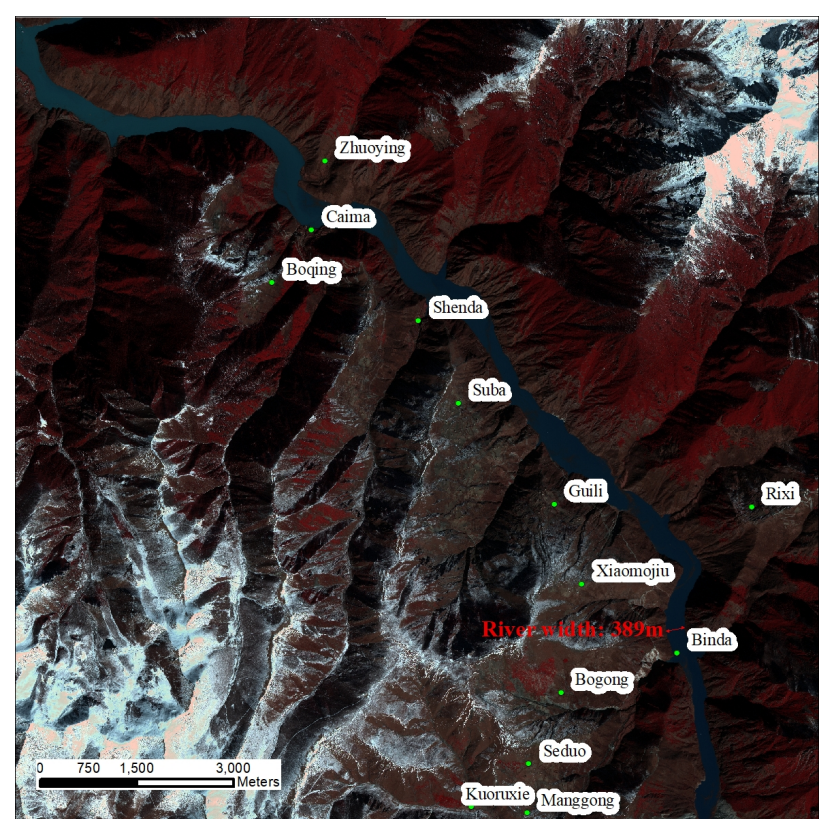

Figure 8. False colour composite BJ-2 image on Nov 9, 2018

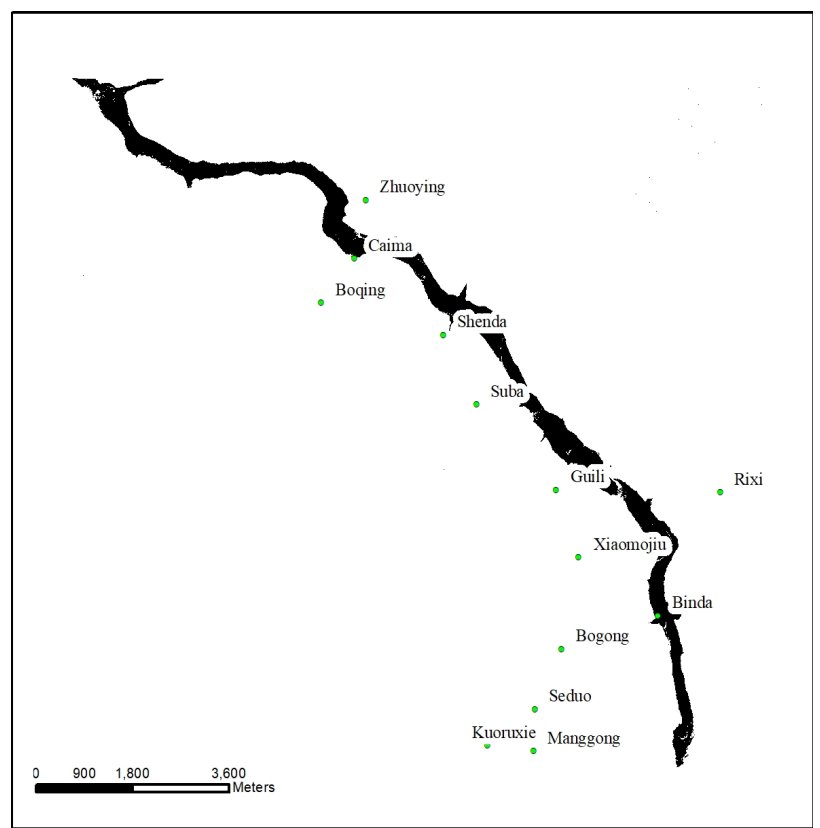

Figure 9. Water extraction result from BJ-2 image

remote sensing image, including BJ-2 image (on Nov 9, 2018), Sentinel-1A image (on Nov 4, 2018) and GF-2 image (on Nov 1 , 2018). Figure 4 and Figure 5 were pre-disaster and post-disaster images respectively. Figure 4 showed river width at Binda was $142 \mathrm{~m}$ and Figure 5 showed $190 \mathrm{~m}$ weir crest width and $280 \mathrm{~m}$ weir crest length on post-disaster image.

Figure 6 was false colour composite BJ-2 image and Figure 7 was water extraction result. Meanwhile, Figure 8 was Sentinel1A image and Figure 9 was water extraction result. After the preconditioning of remote sensing images, Extraction of landslide lake water result showed in Figure 7 and Figure 9. Black zone represented water area and white zone indicated non-water areas. We could analyze landslide lake change based on water area changes. Landslide lake water area increased from 
$3,606,685 \mathrm{~m}^{2}$ on November 4,2018 to $161,012,128 \mathrm{~m}^{2}$ on November 11, 2018

ss

\section{CONCLUSION AND SUGGESTION}

\subsection{CONCLUSION}

Landslide lake, as a second geological disaster with potential hazard always caused huge disaster result from landslide dam break. Remote sensing technology, as an objective, fleet and dynamic tool with wide monitoring range, had a great advantage in landslide lake monitor. With the development of remote sensing technology, remote sensing big data could meet the requirement of all-weather dynamic monitor of landslide lake, which would provide basic information of landslide lake for decision-making departments to make disaster prevention and reduction.

In aspect of actual landslide lake monitor, this study systematically introduced the application of remote sensing big data for landslide lake monitor. After the occurrence of landslide lake, we should select suitable remote sensing images, if it was cloudy, radar images were collected. If it was not cloudy, optical images were collected. Then, some necessary precondition steps were carried out. Lastly, we would construct remote sensing images for landslide lake monitor in time series.

\subsection{SUGGESTION}

In landslide lake disaster monitor, we should considerate using aerial image and drone image to monitor landslide lake disaster. Especially it is cloudy, drone image could obtain higher resolution optical images. Besides, drone image also obtained topographic data, which played a vital role in landslide lake disaster relief. Nowadays, application of remote sensing big data meet real-time dynamic monitor of landslide lake. The next step will focus on predicting landslide lake water level based on remote sensing, rainfall forecasting products, hydrological model. Lastly, assessing appearance time of dam overtopping and evaluating the stability of landslide dam by dam parameters should be considered were based on geotechnical mechanics knowledge.

\section{ACKNOWLEDGEMENTS}

This work was supported by the National Key Research and Development Program of China (Grant No: 2017YFB0504100; 2016YFC0803000).

\section{REFERENCES}

Dai, F., Lee, C. F.*, Deng, J., Tham, L. G., 2005. The 1786 earthquake-triggered landslide dam and subsequent dam-break flood on the Dadu River, southwestern China. Geomorphology, 65(3-4): 205-221.

Dong, J. J.*, Tung, Y. H., Chen, C. C., Liao, J., Pan, Y., 2009. Discriminant analysis of the geomorphic characteristics and stability of landslide dams. Geomorphology, 110 (3): 162-171.

Dong, J. J.*, Lai, P. J., Chang, C. P., Yang, S. H., Yeh, K. C., Liao, J. J., Pan, Y. W., 2014. Deriving landslide dam geometry from remote sensing images for the rapid assessment of critical parameters related to dam-breach hazards. Landslides, 11(1): 93-105.

Du, J.*, Shi, C. X., Zhang C. D., 2013. Modeling and analysis of effects of precipitation and vegetation coverage on runoff and sediment yield in Jinsha River Basin. Water Science and Engineering, 6 (1): 44-58.

Fan, J. R.*, Chen, J. X., Tian, B. W., Yan, D., Cheng, G. W., Gui, P., Zhang, W., 2010. Rapid Assessment of Secondary Disasters Induced by the Wenchuan Earthquake. Computing in science and engineering, 12 (1): 10-19.

Fan, X. M.*, Cees, J., Westen, V., Korup, O., Gorum, T., Xu, Q., Dai, F. C., Huang, R. Q., Wang, G. H., 2012. Transient water and sediment storage of the decaying landslide dams induced by the 2008 Wenchuan earthquake, China. Geomorphology, 57: 58-68.

Fan, X. M.*, Westen, C. J. V., Xu, Q., Gorum, T., Dai, F. C., 2012. Analysis of landslide dams induced by the 2008 Wenchuan earthquake. Journal of Asian Earth Sciences, 57: 2537

Hoque, M. A.*, Phinn, S., Roelfsema, C., Childs, I., 2017. Tropical cyclone disaster management using remote sensing and spatial analysis: A review. International Journal of Disaster Risk Reduction, 22: 345-354.

Hou, J. M., Ma L. P., Chen, Z. Y., Qi, W. C., Wang, L., 2019. High-performance numerical simulation for dam-break flood propagation of Baige barrier lake in Jinsha river. Yang River, 50 (4): 65-70. (In Chinese)

Kaku, K.*, Satellite remote sensing for disaster management support: A holistic and staged approach based on case studies in Sentinel Asia. International Journal of Disaster Risk Reduction, 33: 417-432.

Liu, L. Y.*, Wu, Y. H., Zuo, Z. L., Chen, Z. C., Wang, X. X., Zhang, W. J., 2009. Monitoring and assessment of barrier lakes formed after the Wenchuan earthquake based on multitemporal remote sensing data. Journal of Applied Remote Sending, 3.

Liu, Q. R., Ruan, C. Q.*, Zhong, S., Li, J., Yin, Z. H., Lian, X. H., 2018. Risk assessment of storm surge disaster based on numerical models and remote sensing. International Journal of Applied Earth Observation and Geoinformation, 68: 20-30.

Liu, Y.*, Wu, L. Z., 2016. Geological Disaster Recognition on Optical Remote Sensing Images Using Deep Learning. Procedia Computer Science, 91: 566-575.

Morris, M. W., Galland, J. C., 1988. CADAM: Dam break modelling guideline \& best practice. Munich HR Wallingford Ltd.

Peng, M., Zhang, L. M*., Chang, D. S., Shi, Z. M., 2014. Engineering risk mitigation measures for the landslide dams induced by the 2008 Wenchuan earthquake. Engineering Geology, 180 (SI): 68-84.

Sharma, T. P. P., Zhang, J. H.*, Koju, U. P., Zhang, S., Bai, Y., Suwal, M. K., 2019. Review of flood disaster studies in Nepal: A remote sensing perspective. International Journal of Disaster Risk Reduction, 34: 18-27. 
Shi, Z. M.*, Wang, Y. Q., Peng, J. F., Yuan, J., 2015. Characteristics of the landslide dams induced by the 2008 Wenchuan earthquake and dynamic behaviour analysis using large-scale shaking table tests. Engineering Geology, 194: 2537

Song, M. B., Li, T. X., 2012. Chen, J. Q.*, 2012. Preliminary Analysis of Precipitation Runoff Features in the Jinsha River Basin. Procedia Engineering, 28: 688-695.

Torbick, N.*, Ledoux, L., Salas, W., Zhao. M., 2016. Regional mapping of plantation extent using multisensor imagery. Remote Sens., 8 (3): 1-21

Wang, G. H.*, Huang, R. Q., Kamai, T., Zhang, F. Y., 2013. The internal structure of a rockslide dam induced by the 2008 Wenchuan (Mw7.9) earthquake, China. Engineering Geology, 156:28-36.

Wang, L., Chen, Z. Y.*, Wang, N. X, Sun, P., Li, S.Y., Du, X. H., 2016. Modelling lateral enlargement in dam breaches using slope stability analysis based on circular slip mode. Engineer Geology, 209: 70-81.

Westen, C. J. V., 2013. 3.10 Remote Sensing and GIS for Natural Hazards Assessment and Disaster Risk Management. Treatise on Geomorphology, 3: 259-298.

Xiong, J. G., Wang, L. T., Wang, S. X., Zhou, Y., 2012. Microwave water extraction supported by multi-spectral images. Journal of China Institute of Water Resources and Hydropower Research, 10 (1): 23-35. (In Chinese)

Xu, M., Cao, C. X.*, Zhang, H., Guo, J. P., Nakane, K., He, Q. S., Guo, J. H., Chang, C. Y., Bao, Y. F., Gao, M. X., Li, X. W., 2010. Change detection of an earthquake-induced barrier lake based on remote sensing image classification. International Journal of Remote Sensing, 31(13): 3521-3534.

Xu, Q.*, Fan, X. M., Huang, R. Q., Westen, C., 2009. Landslide dams triggered by the Wenchuan Earthquake, Sichuan Province, south west China. Bulletin of Engineering Geology and the Environment, 68 (3): 373-386.

Yang, C. J., Wei, Y. M., Chen, D. Q., 1998. Investigation on extraction the flood inundated area from JERS-1 SAR data. Natural disaster, 7(3): 46-50. (In Chinese)

Yang, Q. G., Zhou, H., 2008. Barrier lake classification and safety standard conception. Yangtze River, 29 (22): 17-18.(In Chinese)

Yao, Y., Shen, Q., Zhu, L., Gao, H. J., Cao, H. Y., Han, H., Sun, J. G., Li, J. S., 2019. Remote sensing identification of urban black-odor water bodies in Shenyang city based on GF-2 image. Journal of Remote Sensing, 23(2): 231-241. (In Chinese)

Yi, S. Z., Wang, Z. H., 2007. Application of different methods extraction by Remote Sensing. Infrared, 28(4): 1-4. (In Chinese)

Yuan, Q. S., Wang, P. F.*, Wang, C., Chen, J., Liu, S., F, T., 2019. Metals and metalloids distribution, source identification, and ecological risks in riverbed sediments of the Jinsha River, China. Journal of Geochemical Exploration, 205: 1-9.
Zhang, W. J.*, Wang, W. H.*, Wu, F. Q., 2012. The Application of Multi-variable Optimum Regression Analysis to Remote Sensing Imageries in Monitoring Landslide Disaster. Energy Procedia, 16 (A): 190-196.

Zhang, Y. H., Zhao, X. T., Lan, H. X., Xiong, T. Y., 2011. A Pleistocene landslide-dammed lake, Jinsha River, Yunnan, China. Quaternary International, 233 (1): 72-80.

Zhu, S., 2012. River landform and geology environment evolution in Yarlung Zangbo River valley. Academy of Geological Sciences. 